\title{
Adhesion of ectomycorrhizal bacteria to plant cells: an in vitro evidence
}

\author{
B. Citterio, V. Patrone, B. Baldelli,* M. Malatesta*
}

Istituto di Scienze Tossicologiche, Igienistiche e Ambientali and * Istituto di Istologia e Analisi

di Laboratorio, University of Urbino "Carlo Bo", Urbino, Italy

(C)2004, European Journal of Histochemistry

In this study we have investigated, by combining microbial and microscopical techniques, the adhesion ability of bacteria present in Tuber borchii ectomycorrhizosphere. Our data demonstrate that a common pool of bacteria - Pseudomonas, Bacillus, Micrococcus and Moraxella - occurs in all ectomycorrhizal homogenates and that most of these bacteria are able to attach in vitro to plant cells.

Key words: bacteria, adhesion, ectomycorrhiza, Tuber.

Correspondence: Manuela Malatesta, Istituto di Istologia e Analisi di Laboratorio, via Zeppi s.n., University of Urbino

"Carlo Bo", 61029 Urbino, Italy.

Phone: international +39.0722.320168.

Fax: international +39.0722 .322370 .

E-mail: malatesta@uniurb.it

Paper accepted on December 19, 2003

European Journal of Histochemistry

2004; vol. 48 issue 2 [Apr-Jun]: 191-194
$\mathrm{M}$ ycorrhizal symbioses occur in the "mycorrhizosphere", defined as the rhizosphere of a root infected by a mycorrhizal fungus. As the fungus uses some of the root exudates and modifies root functions, microbial communities in the mycorrhizosphere differ from those in the rhizosphere and in the soil (Ames et al., 1984; Linderman, 1988; Bianciotto, 2001). Bacteria are often associated with ectomycorrhizas and are probably involved in the dynamics of mycorrhiza formation (Garbaye and Duponnois, 1992; Varese et al., 1996, Gamalero 2003). In this study we investigated, by combining microbial and microscopical techniques, some bacterial strains of Tuber borchii ectomycorrhizosphere and we tested them in vitro for adhesion to plant cells.

Twenty-one samples of $T$. borchii ectomycorrhizas of different botanical species were harvested in mountain areas of the Comunità Montana dell'Alto e Medio Metauro (Central Italy) and identified by morphological analysis of the mantle. Mycorrhized apices ( $1 \mathrm{~g}$ f.w.) were aseptically collected, submitted to 4 washings in sterile physiological solution $(8.5 \mathrm{~g} \mathrm{NaCl} / \mathrm{L})$ to remove external bacteria and homogenised with a potter (10 min). Homogenates suspensions were diluted, placed on TSA (Triptone Soy Agar, Difco) and incubated for $36-48 \mathrm{~h}$ at $28^{\circ} \mathrm{C}$ to evaluate the microbial growth. After a preliminary screening (Gram staining, oxidase and catalase tests, sugar reduction), bacteria occurring in all ectomycorrhizal homogenates were identified. After being placed on TSA medium, the appropriate dilutions were maintained for $10 \mathrm{~min}$ at $80^{\circ} \mathrm{C}$ to discriminate for the Bacillus. The bacterial colonies were purified, identified using API systems (Biomerieux-France) and biochemical analysis according to Bergey's manual, and finally cryopreserved at $-20^{\circ} \mathrm{C}$ in glycerol. We found that all ectomycorrhizal homogenates contained bacterial strains belonging to the genera Pseudomonas, Bacillus, Micrococcus and Moraxella. A total of 25 


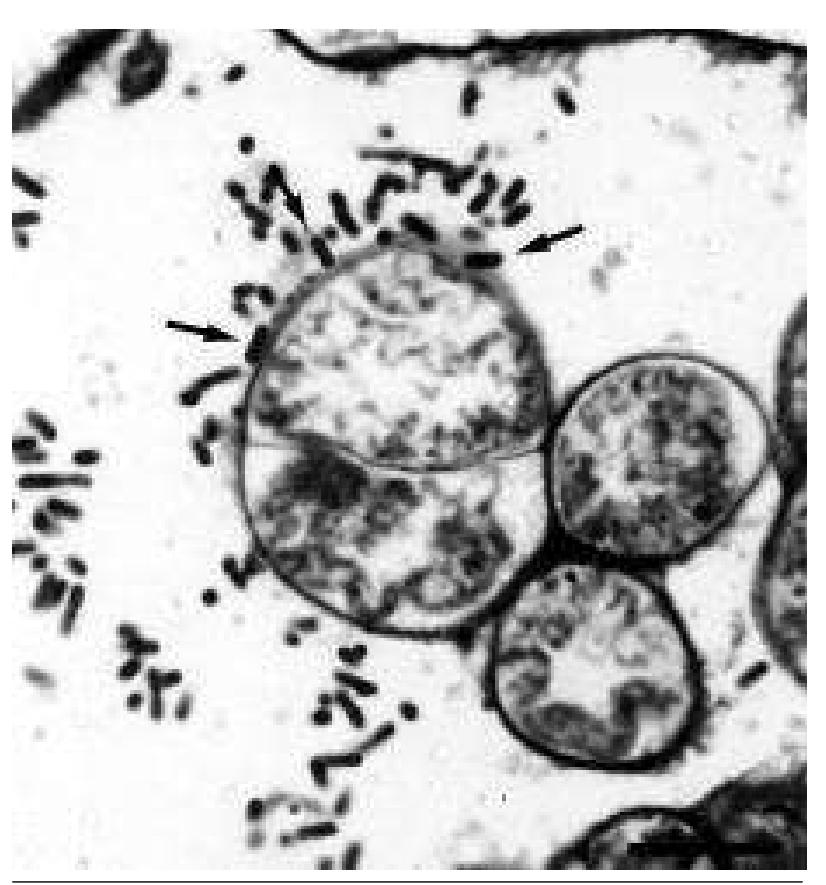

Figure 1. Bacteria occur in association with Rubus fruticosus cell surface (arrows). Scale bar: $10 \mu \mathrm{m}$.

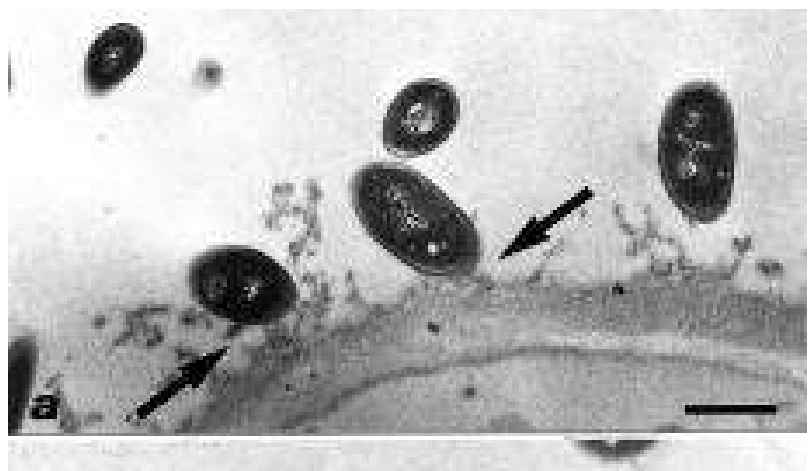

b

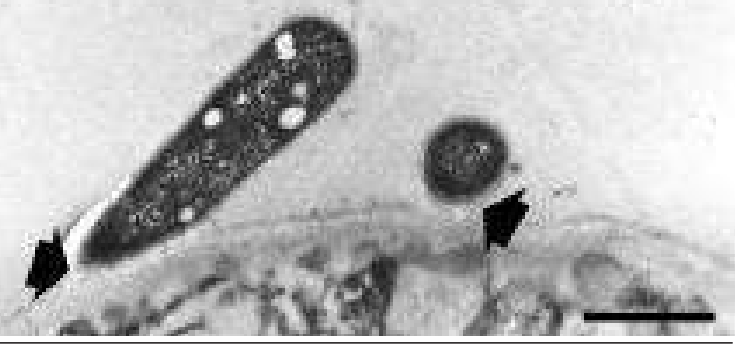

Figure 2. Bacteria belonging to the genus Pseudomonas attached to Rubus frut/cosus cells: some of them (a) are embedded in the fine fibrillar material coating the cell surface (arrows), others make direct contact with the cell wall (arrowheads). Scale bars: 1 rm.

bacterial strains from these genera were used to test their possible attachment to plant cells. Rubus fruticosus cells, a widespread and reliable in vitro

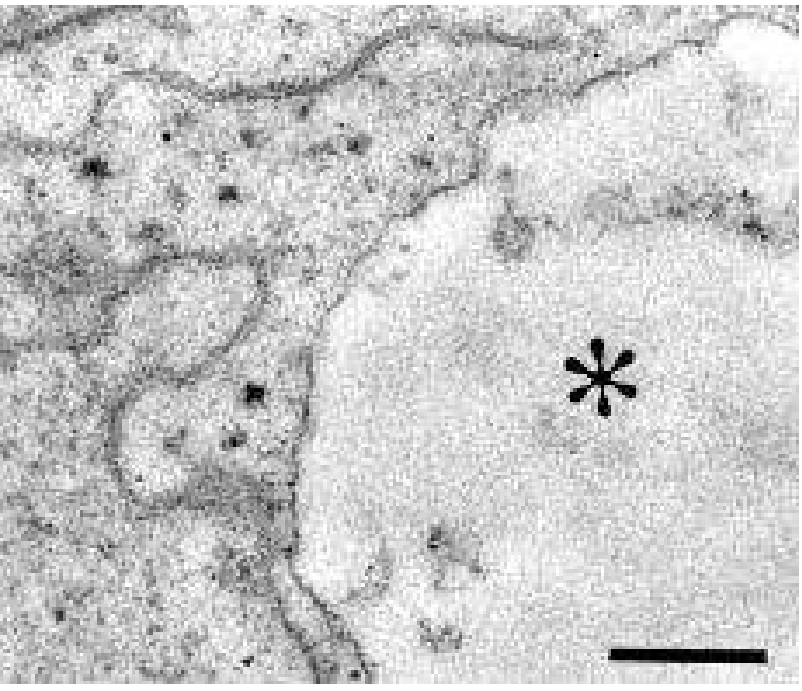

Figure 3. In the cytoplasm of Rubus frut/cosus cells various membranous structures and vacuoles (asterisk) are present. Scale bar: $0.5 \mu \mathrm{m}$. model, were grown in KM (Kao and Michayluk) medium (Mezzetti et al., 1997). Ten mL plant cell culture were inoculated in $100 \mathrm{ml} \mathrm{KM}$ medium and incubated at $24^{\circ} \mathrm{C}$ in an orbital shaker at $115 \mathrm{rpm}$ in the dark. The different bacterial strains were grown for $24 \mathrm{~h}$ in order to obtain a synchronous culture and the viability was tested using 5-Cyano2,3-ditolyl tetrazolium chloride (Polysciences Europe $\mathrm{GmbH}$ ). A loop of these bacteria $\left(10^{3}\right.$ $\mathrm{CFU} / \mathrm{mL}$ ) was then added to $100 \mathrm{~mL} \mathrm{KM}$ medium containing $10^{5}$ plant cells and kept at $24^{\circ} \mathrm{C}$ in the orbital shaker for 2 days. The samples were then washed twice with sterile physiological solution, filtered and resuspended in the culture medium. In order to preserve a good ultrastructural morphology of both bacterial and plant cells as well as the cell-bacteria relationships (Figures 2 and 3), the cell suspensions were fixed by adding $2.5 \%$ glutaraldehyde directly to the culture medium. After 1 $\mathrm{h}$ fixation at $4^{\circ} \mathrm{C}$, the cells were washed in $0.2 \mathrm{M}$ cacodylate buffer $\mathrm{pH} 5.6$, post-fixed with $1 \% \mathrm{OsO}_{4}$ for $1 \mathrm{~h}$, washed again, dehydrated and embedded in LRWhite resin. Semithin sections, stained with 1\% toluidine blue, were observed with a Leitz Orthoplan light microscope and revealed the presence of bacteria and their distribution among the plant cells. As expected, the bacterial population present in each sample was constituted by morpho- 
logically homogeneous individuals, showing either rod-like or ovoid shapes. In 23 of the 25 samples analysed numerous bacteria appeared to be associated to the plant cell surface (Figure 1$)$; in detail 10 samples showed a weak ( $8-10$ bacteria/cell), 10 a moderate (10-20 bacteria/cell) and 3 a strong (more than 30 bacteria/cell) attachment. The adhering bacteria belonged to all the tested genera, but two Pseudomonas strains were non-adhering. Ultrathin sections, contrasted with lead citrate, were observed with a Zeiss EM 902 electron microscope, thus revealing the fine spatial relationships between bacterial and plant cells. Bacteria were observed adhering by means of the fine fibrillar material coating the plant cell surface (Figure 2a) as well as by making direct contact with the plant cell wall (Figure $2 b$ ).

In conclusion, our data demonstrate that, in spite of the various host plants, a common pool of bacterial strains - Pseudomonas, Bacillus, Micrococcus and Moraxella - occurs in T. borchii ectomycorrhizosphere, and most of these bacteria are able to attach in vitro to plant cells. It is likely that such bacteria would be related with $T$. borchii life cycle, as suggested by their presence in the sporocarps of the same fungus (Citterio et al., 1995), where they seem to be involved in ascus opening by producing cellulolytic and chitinolytic enzymes (Gazzanelli et al., 1999; Citterio et al., 2001). Some of these bacteria are known to attach to root cells (Hawes and Brigham, 1992); moreover, Pseudomonas species isolated from $T$. borchii ascocarps have been demonstrated to adhere to Tuber hyphae (Sbrana et al., 2000; Sbrana et al., 2002). As our in vitro model showed, the microbial attachment can take place by means of the mucilaginous material coating plant cells, but the bacteria can also establish a direct contact with the plant cell wall.

\section{Acknowledgments}

We are particularly grateful to Prof. Bruno Mezzetti for providing us with Rubus fruticosus cells.

\section{References}

Ames RN, Reid CPP, Ingham ER. Rhizosphere bacterial population response to root colonization by a vesicular-arbuscular mycorrhizal fungus. New Phytol 1984;96:555-63.

Bianciotto V Andreotti S, Balestrini R, Bonfante P, Perotto S. Extracellular polysaccharides are involved in the attachment of Azospirillum brasilense and Rhizobium leguminosarum to arbuscolar mycorrhizal structures. Eur J Histochem 2001;45:39-49.

Citterio B, Cardoni P, Potenza L, Amicucci A, Stocchi V, Gola G, et al. Isolation of bacteria from sporocarps of Tuber magnatum Pico, Tuber borchii Vitt. and Tuber maculatum Vitt. Identification and biochemical characterization. In: Stocchi $V$, Bonfante $P$, Nuti MP, editors. Biotechnology of ectomycorrhizae. Plenum Press: New York; 1995. p. 241-8.

Citterio B, Malatesta M, Battistelli S, Marcheggiani F, Baffone W, Saltarelli R, et al. Possibile involvement of Pseudomonas fluorescens and Bacillaceae in structural modifications of Tuber borchii fruit bodies. Can J Microbiol 2001;47:264-8.

Gamalero E, Fracchia L, Cavaletto M, Garbaye J, Frey-Klett P, Varese G.C, Martinotti M.G. Characterization of functional traits of two fluorescent pseudomonas isolated from basidiomes of ectomycorrhizal fungi. Soil Biol Biochem 2003;35: 55-6.

Garbaye J, Duponnois R. Specificity and function of mycorrhization helper bacteria (MHB) associated with the Pseudostuga menziesiiLaccaria laccata symbiosis. Symbiosis 1992;14:335-44.

Gazzanelli G, Malatesta M, Pianetti A, Baffone W, Stocchi V, Citterio B. Bacteria associated to fruit bodies of the ecto-mycorrhizal fungus Tuber borchii Vittad. Symbiosis 1999;26:211-22.

Hawes MC, Brigham LA. Impact of root border cells on microbial populations in the rhizosphere. Adv Plant Pathol 1992;8:119-48.

Linderman RG. Mycorrhizal interaction with the rhizosphere microflora: the mycorrhizosphere effect. Phytopatology 1988;78:366-71.

Mezzetti B, Savini G, Carnevali F, Motti D. Plant genotype and growth regulator interaction affecting in vitro morphogenesis of blackberry (Rubus fruticosus) and raspberry ( $R$. idaeus). Biol Plantarum 1997; 39:139-50.

Sbrana C, Bagnoli G, Bedini S, Filippi C, Giovannetti M, Nuti MP. Adhesion to hyphal matrix and antifungal activity of Pseudomonas strains isolated from Tuber borchii ascocarps. Can J Bot 2000; 46: 259-68.

Sbrana C, Agnolucci M, Bedini S, Filippi C, Lepera A, Toffanin A, Giovannetti M, Nuti MP. Diversity of culturable bacteria populations associated to Tuber borchii ectomycorrhizas and their activity on $T$. borchii mycelial growth. FEMS Microbiol Lett 2002;2:195-201.

Varese GC, Portinaro S, Trotta A, Scanerini S, Luppi-Mosca AM, Martinotti MG. Bacteria associated with Suillus grevillei sporocarps and ectomycorrhizas and their effects on in vitro growth of the mycobiont. Symbiosis 1996;21:129-47. 
B. Citterio et al. 